\title{
Carta del General de Hombres y Mujeres Libres Augusto C. Sandino
}

El Chipotón, 10 de Junio de 1928.

Grande estimado maestro y amigo:

Con profunda sorpresa leí en Ariel del $1^{\circ}$ de Mayo último, sus palabras editoriales, relativas al peligro en que se halla la integridad territorial de Honduras, en lo que respecta a la cuestión de límites con Guatemala. Tanto sus palabras, como las que reproduce del editorial de El Cronista de esa ciudad, hicieron que sintiera por un momento helada mi sangre. Pronto comprendí que personajes de la política imperialista yanqui, son los atizadores de esta hoguera centroamericana.

En estos instantes me preocupan más las graves dificultades entre ustedes, los dirigentes de Centro América, o sea la Patria Grande, que la causa que yo mismo estoy defendiendo con mis pocos centenares de bravos; porque me convenzo que con nuestra firmeza de ánimo y el terror que hemos logrado sembrar en el corazón de los piratas, nuestro final será evidente, mientras tanto que ustedes están rodeados de patricidas que siempre andan al olfato de las causas grandes, para dejar en ellas la semilla de la traición.

En nombre de Nicaragua, de Honduras, de Guatemala y en nombre de Dios, querido amigo mío, yo le suplico a usted y a todos los hombres de entendimiento y claro patriotismo de América Central, traten de evitar por todos los medios posibles, el acaloramiento de ánimos y la ruptura de nosotros mismos. Ustedes están en la obligación de hacer comprender al pueblo de América Latina, que entre nosotros no deben existir fronteras y que todos estamos en el deber preciso de preocuparnos por la suerte de cada uno de los pueblos de la América Hispana, porque todos estamos corriendo la misma suerte ante la políticá colonizadora y absorbente de los imperialistas yanquis. Las bestias rubias están colocadas en uno de los extremos de la América Latina y desde allí observan ávidas nuestros movimientos políticos y económicos: ellos conocen nuestra ligereza de carácter y procuran mantener latente entre uno y otro país nuestros graves problemas sin resolver. Por ejemplo, la cuestión de límites entre Guatemala y Honduras, entre Honduras y Nicaragua: el asunto canalero entre Nicaragua 
y Costa Rica, la cuestión del Golfo de Fonseca entre El Salvador, Honduras y Nicaragua; la cuestión de Tacna y Arica entre Perú y Chile. Y así por el estilo, hay un encadenamiento de importantes asuntos en resolución entre nosotros. Los yanquis nos tienen bien estudiados y se aprovechan de nuestro estado de cultura y de la ligereza de nuestros caracteres para hacemos peligrar siempre que a los intereses de ellos conviene.

Tomando como se debe, por lema las frases anteriores, los yankees sólo pueden venir a nuestra América Latina como huéspedes; pero nunca como amos y señores, como pretenden hacerlo. No será extraño que a mí y a mi Ejército se nos encuentre en cualquier país de la América Latina donde el invasor asesino fije sus plantas en actitud de conquista.

Sandino es indohispano y no tiene fronteras en la América Latina. Sin más que recomendarle por ahora, querido maestro, le envío mi corazón, con el cual le hablo en esta carta.

Patria y libertad.

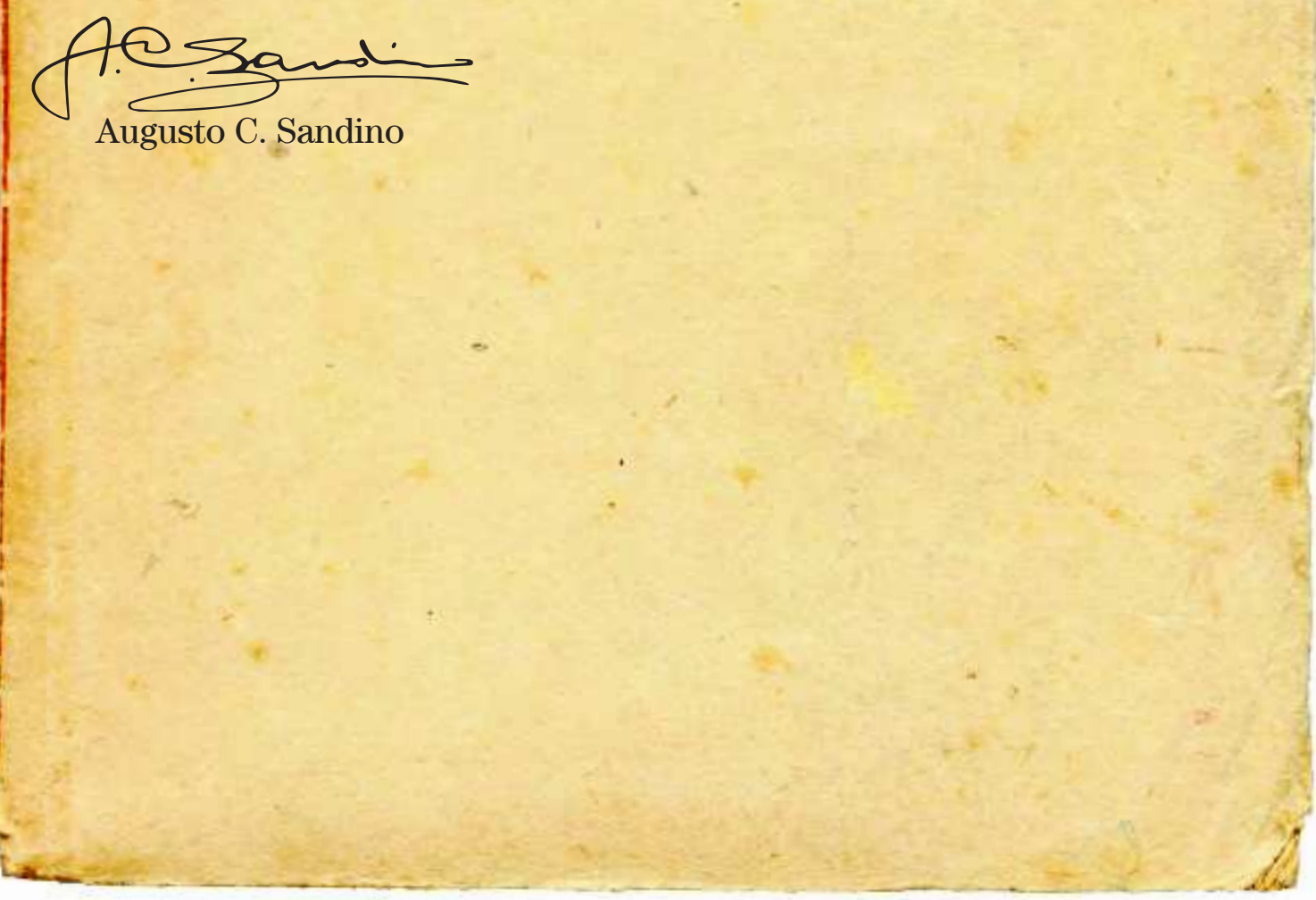

